\title{
Clinical Use of the Interferon Inducer IIBI in Patients with Refractory Hodgkin's Lymphoma
}

\author{
Daniar R. Aspetov ${ }^{1}$; Maria N. Omarova ${ }^{1}$; Lyazzat Zh. Orakbay*1; \\ Raiymkul K. Karakulov²; Kairat S. Doskhozhayev²; Bayan Kh. Zhumatova'; \\ Meruyert D. Chazhayeva ${ }^{1}$ \\ ${ }^{1}$ Scientific Centre of Hygiene and Epidemiology \\ ${ }^{2}$ Kazakh Research Institute of Oncology and Radiology \\ Almaty, Kazakhstan
}

\begin{abstract}
This study evaluated the effects of the immunobiological preparation "Interferon inducer bacterial liquid" (IIBI) combined with chemoradiotherapy (CRT) in patients with refractory Hodgkin's lymphoma (HL) are presented. The clinical application of IIBI increases the efficacy of treatment. IIBI in combination with CRT induces the production of highly active endogenous IFN$\alpha / \beta$, provides a marked regression of the affected lymph nodes in a short period (within 7 to 10 days) of treatment, relieves $B$ symptoms, and increases by 2 times the length of remission in patients with refractory HL. (Int J Biomed. 2015; 5(4):214-218.)
\end{abstract}

Keywords: Hodgkin's lymphoma; chemoradiotherapy; IFN- $\alpha / \beta$; IFN inducer.

\section{Introduction}

Hodgkin's lymphoma (HL) is a heterogeneous malignancy with a complex etiology and epidemiology. Therapy for classical HL has considerably improved during the last two decades [1]. With current therapeutic approaches consisting of polychemo- and small-field radiotherapy, up to $80 \%$ of all patients can be cured long term. In refractory or relapsed HL, intensified treatment including highdose chemotherapy (HDCT) and autologous stem cell transplantation (ASCT) is associated with progression-free survival (PFS) of $50 \%$. [2]. The long-term toxicity of current regimens, however, is still strikingly high, providing a need for alternative strategies. Evaluating novel drugs in multiple relapsed or refractory cases and reducing treatment-related side effects are the focus of modern research.

The blockade of immunological checkpoints has been successfully employed for the treatment of various solid neoplasms [3]. A recent study indicates that the vast majority of patients with advanced, heavily pretreated HL also respond to a monoclonal antibody targeting programmed cell death 1

*Corresponding author: Lyazat Orakbay, PhD, ScD. Scientific Centre of Hygiene and Epidemiology named after Hamza Zhumatov. Almaty, Kazakhstan.E-mail: ncgigieny@mail.ru
(PD-1) [4]. Thus, checkpoint blockers may soon become part of our therapeutic armamentarium against hematological tumors. This would be particularly important as it would spare (at least some) patients the deleterious toxic effects of combinatorial chemotherapies and bone marrow transplantation.

Immunotherapy of Hodgkin's lymphoma, however, has to take into account that the malignant $\mathrm{CD} 30^{+}$Hodgkin/ Reed-Sternberg cells (H/RS) persist in small numbers in the lymphoma lesion and are accompanied by massive infiltrations with benign cells [5-9]. H/RS cells secrete a variety of cytokines and chemokines favoring a $\mathrm{T}$ helper-2 (Th2) immune response which likely contributes to disease progression through restraining cellular reactivity [6], [10-12].

Type I interferons (endogenously produced IFN- $\alpha / \beta$ ) are important components of the cancer immunoediting process [13]. The fact that IFNs can bring about long-term remissions in certain malignancies is well established [14-19].

Type I IFN is represented by several partially homologous genes of IFN- $\alpha$ and a single gene of IFN $-\beta$ and those genes can be expressed by almost any type of cell in response to stimulation of an array of receptors by pathogens [20]. Regarding that, type I IFN are more than just anti-viral as they play a major role in linking innate to adaptive immunity [21-23]. IFN- $\alpha$ is a type of interferon that may be effectively used to treat lymphoma $[24,25]$. Yet experts remain uncertain 
about the benefits of interferon, and there are questions about its suitability in combination with chemotherapy. N. Batty et al. [25] performed a phase II trial to determine the safety and effectiveness of IFN- $\alpha$ and standard doxorubicin, bleomycin, vinblastine and dacarbazine (ABVD) chemotherapy (IABVD) in patients with newly diagnosed advanced stage classic Hodgkin lymphoma (HL). Treatment consisted of six cycles of ABVD with concurrent IFN- $\alpha$ followed by radiation therapy if indicated. The 3-year event-free survival rate was $71 \%$ (95\% confidence interval [CI], 56-90\%), and the 3 -year overall survival rate was $96 \%$ (95\% CI, $89-100 \%)$. Continued research is needed to improve the long-term survival of $\mathrm{HL}$ patients and to lessen the toxicities associated with therapy. It should be noted that many preparations of synthetic interferon applied in the clinic are quite expensive and not without side effects. An alternative and more harmless method is interferonization with the induction of endogenous interferon. Classically, exposure of cells to type I IFN induces an antiviral state that prevents productive viral infection. This premise was postulated by Isaacs and Lindenmann about 60 years ago when they demonstrated the cell ability to resist a virus infection. This phenomenon was then attributed to type I IFN cytokine considered the factor responsible to interfere in the viral infection [26].

Besides viruses, an increased number of pathogens, such as bacteria, protozoa, and fungi, have been reported to be inducers of type I IFN [21,27-29]. Type I IFN related to prevent bacterial infection was first demonstrated for pathogens from Chlamydia genus [30]. The limitation of bacterial infection by type I IFN induction was also observed in the case of C. pneumoniae and Legionella pneumophila [31,32]. The augmentation of pro-apoptotic stimulus in macrophages and lymphocytes was described in infection with Listeria, Mycobacteria, and Chlamydia spp [33-35].

In 2005, the first observation that Brucella induces type I IFN was made by L. Huang et al. [36] when IFN- $\alpha$ was detected in serum of wild type mice injected with HKBa and the level was markedly reduced in the $\mathrm{TLR}^{-/-}$mice serum, demonstrating that HKBa induces IFN- $\alpha$ in a TLR9-dependent manner. Additionally, it has shown that $B$. abortus is able to induce IFN- $\beta$ in DCs [37].

In 2012, the new bacterial INF inducer IIBI was developed in the Laboratory of Virology at the Scientific Center for Hygiene and Epidemiology (Kazakhstan) and included in the State Register of medicinal products to treat cancer patients. IIBI contains a unique bacterial substance (Brucella melitensis $)$ and induces the production of endogenous INF- $\alpha / \beta$ [38]. Studies to assess the antitumor properties of IIBI were performed in the Kazakh Research Institute of Oncology and Radiology during 2012-2014.

The purpose of this study was to explore the interferonogenic, anti-inflammatory, and detoxifying properties of IIBI on the background of CRT in patients with refractory HL.

\section{Materials and methods}

The study included 138 patients with refractory HL (from 30 to 55 years). The disease duration ranged from 1 to 11 years. The diagnosis of HL was confirmed histologically via an endoscopic biopsy of the mediastinal or abdominal lymph nodes. Patients had Ann Arbor stage II (54.3\%), III $(41.3 \%)$ or IV $(4.3 \%)$ disease. B symptoms were observed in $77.5 \%$ of patients.

Histological sub-classification was performed in line with WHO classification [39]: nodular lymphocyte predominant HL (NLPHL) and classic HL (nodular sclerosis $\mathrm{HL}$, lymphocyte rich classic HL, mixed cellularity HL, and lymphocyte depleted HL).

Immunohistochemistry (IHC) was performed using an antibody panel for Reed-Sternberg cells (RSCs). Sections were analyzed by a semi-quantitative method, which differed depending on the antibody used. Antibodies against CD15, CD30, CD3, CD20, CD45, EMA and EBV LMP-1 were used for paraffin section IHC. Of the panel of antibodies, CD30 was the most useful in identifying RSCs in classical HL. IHC was also used for differential diagnosis between non-HL and NLPHL [40].

According to the therapy regimen, patients were divided into 2 groups. Study group patients (Group 1, $n=70$ ), after 6 months of their last CRT course (6 cycles of ABVD/MOPP and radiation therapy), were assigned to intramuscularly IIBI (10MM IU/ml) injections every other day (first 3 injections), and after that one injection per week for 4 weeks. Immediate and 2-year outcomes of treatment were identified. In the control group (Group 2, n=68), IIBI was not administered according to protocol.

After each IIBI injection, we determined serum IFN- $\alpha / \beta$ activity. Serum IFN- $\alpha / \beta$ was defined by the micromethod in plastic 96-well microtiter trays with a monolayer of RD cells, according to A. Novokhatskiǐ et al. [41]. Determination of Tand B-lymphocytes was performed by an E-rosette test and EAC-rosette test, respectively. Side effects of IIBI therapy were analyzed.

The study was conducted in line with the requirements of the World Medical Association Declaration of Helsinki "Ethical Principles for Medical Research Involving Human Subjects" (2008). It was approved by the Kazakh Research Institute of Oncology and Radiology Ethics Committee. Written informed consent was obtained from all participants.

Statistical analysis was performed using StatSoft Statistica v6.0 Baseline characteristics were summarized as frequencies and percentages for categorical variables and as mean \pm SEM for continuous variables. Student's unpaired and paired t-tests were used to compare two groups for data with normal distribution. Group comparisons with respect to categorical variables are performed using chi-square tests or, alternatively, Fisher's exact test when expected cell counts were less than 5 . A probability value of $P<0.05$ was considered statistically significant.

\section{Results}

As can be seen from Table 1, both groups were comparable in terms of Ann Arbor stage, histological type of HL, and $B$ symptoms (fever, night sweats, and weight loss). 
Table 1.

\section{Clinical characteristics of HL patients}

\begin{tabular}{|l|c|c|}
\hline \multicolumn{1}{|c|}{ HL characteristics } & $\begin{array}{c}\text { Group 1 } \\
\text { (CRT+IIBI) } \\
\mathrm{n}=70\end{array}$ & $\begin{array}{c}\text { Group 2 } \\
(\mathrm{CRT}) \\
\mathrm{n}=68\end{array}$ \\
\hline Ann Arbor stage: & $39(55.7)$ & $36(52.9)$ \\
II & $28(40.0)$ & $29(42.6)$ \\
III & $3(4.3)$ & $3(4.4)$ \\
IV & & \\
\hline Histological classification: & $13(18.6)$ & $16(23.5)$ \\
lymphocyte rich classic HL & $18(25.7)$ & $18(26.5)$ \\
nodular sclerosis HL & $20(28.6)$ & $20(29.4)$ \\
mixed cellularity HL & $19(27.1)$ & $14(20.6)$ \\
lymphocyte depleted HL & $16(22,9)$ & $15(22,1)$ \\
\hline Stage A & $54(77,1)$ & $53(77,9)$ \\
\hline Stage B & & \\
\hline
\end{tabular}

In both groups, most patients $(81.9 \%)$ received radiotherapy according to the radical program. The total focal dose on the struck zones was $38-42 \mathrm{Gr}$, on the subclinical zones it was $30-36 \mathrm{Gr}$. Ten and more ABVD (doxorubicin, bleomycin, vinblastine, dacarbazine) or MOPP (mechlorethamine, vincristine, procarbazine, prednisone) regimens were ineffective. In addition to chemoradiotherapy, patients received antitoxic therapy: the antiemetic preparation ondem (12 mg/day), prednisone (10 mg/day), and a weekly infusion of physiological saline during the CRT course. Tumor regression was observed only in $20 \%-30 \%$ of cases. Relapses of the disease occurred after 4-5 months following CRT.

In Group 1, IIBI therapy was well tolerated with no patients requiring IIBI dose reduction or discontinuation because of side effects. The serum IFN- $\alpha / \beta$ activity increased after the first IIBI administration compared to the initial background values $(<2 \mathrm{IU} / \mathrm{ml})$ (Table 2$)$. With increasing frequency of IIBI administration (from first to third injection), the serum IFN- $\alpha / \beta$ activity increased up to the highest level (more than double) after the third injection $(152 \pm 25.8 \mathrm{IU} / \mathrm{ml})$. INF activity induced after 5 to 7 IIBI injections remained on the therapeutic level (within $60 \mathrm{IU} / \mathrm{ml}$ ).

Table 2.

The serum IFN- $\alpha / \beta$ activity after the IIBI administrations

\begin{tabular}{|c|c|c|c|}
\hline \multirow{2}{*}{$\begin{array}{c}\text { Number of } \\
\text { IIBI injections }\end{array}$} & $\begin{array}{c}\text { Quantity of } \\
\text { patients }\end{array}$ & \multicolumn{2}{|c|}{$\begin{array}{c}\text { Activity of serum IFN- } \alpha / \beta \\
\text { (IU/ml) }\end{array}$} \\
\cline { 2 - 4 } & $\begin{array}{c}\text { Before IIBI } \\
\text { administration }\end{array}$ & $\begin{array}{c}\text { After six hours of } \\
\text { IIBI administration }\end{array}$ \\
\hline 1 & 10 & $<2$ & $52.0 \pm 8.6$ \\
\hline 2 & 9 & $48.4 \pm 6.4$ & $84.0 \pm 14.0$ \\
\hline 3 & 10 & $67.2 \pm 12.0$ & $152.0 \pm 25.8$ \\
\hline 4 & 8 & $62.0 \pm 6.6$ & $68.4 \pm 8.2$ \\
\hline 5 & 8 & $50.2 \pm 6.8$ & $59.8 \pm 7.4$ \\
\hline 6 & 8 & $54.6 \pm 6.2$ & $64.8 \pm 6.8$ \\
\hline 7 & 8 & $51.2 \pm 5.4$ & $62.2 \pm 8.4$ \\
\hline
\end{tabular}

After treatment, $B$ symptoms disappeared, affected nodes decreased in size, and laboratory parameters were normalized in $22.5 \%$ of the patients. Clinical improvement was associated with an increase in serum IFN- $\alpha / \beta$ activity. In the remaining $77.5 \%$ of patients with severe symptoms of intoxication, IIBI administration had no significant therapeutic action. In these patients, the serum IFN- $\alpha / \beta$ activity remained low $(39 \pm 9.34$ $\mathrm{IU} / \mathrm{mL}$ ) during treatment.

Hematologic parameters were improved during the first week of therapy. In particular, we noted an increase in the number of lymphocytes $\left(3.3 \pm 0.17\right.$ vs. $4.5 \pm 0.26 \times 10^{9} / 1$, $\mathrm{P}<0.05)$ and a decrease in ESR level $(29 \pm 2.3$ versus $13 \pm 1.9$ $\mathrm{mm} / \mathrm{h}, \mathrm{P}<0.05)$.

The levels of T- and B-lymphocytes in peripheral blood were evaluated in Group 1 patients $(n=57)$ after 4 injections and the full course of IIBI therapy, in Group 2 patients $(n=37)$, and in healthy donors $(\mathrm{n}=10)$ (Table 3$)$. IIBI application had a positive influence on the quantitative content of $\mathrm{T}$ - and B-lymphocytes and reduced the side effects of CRT.

Table 3 .

The levels of $T$ - and B- lymphocytes in peripheral blood of $\mathrm{HL}$ patients during treatment

\begin{tabular}{|l|c|c|c|}
\hline \multicolumn{1}{|c|}{ Group of patients } & $\begin{array}{c}\text { Quantity } \\
\text { of patients }\end{array}$ & $\begin{array}{c}\text { TLC } \\
\%\end{array}$ & $\begin{array}{c}\text { BLC } \\
\%\end{array}$ \\
\hline$\quad \begin{array}{l}\text { Group 2 } \\
\text { Before treatment } \\
\text { After treatment }\end{array}$ & 37 & $21 \pm 3.8$ & $14 \pm 2.3$ \\
\hline$\quad$ Group 1 & 35 & $25 \pm 4.2$ & $22 \pm 3.7$ \\
Before IIBI administration & 57 & $18 \pm 3.0$ & $12 \pm 2.0$ \\
After the 4th IIBI injection & 56 & $38 \pm 6.0^{*}$ & $28 \pm 6.0^{*}$ \\
After full course of IIBI therapy & 54 & $46 \pm 7.7^{*}$ & $37 \pm 6.2^{*}$ \\
\hline Healthy donors & 10 & $55 \pm 3.4$ & $22 \pm 2.7$ \\
\hline
\end{tabular}

TLC-- T-lymphocytes; BLC-- B-lymphocytes; * $P<0.05$ compared to data before IIBI administration

When evaluating the antitumor activity of IIBI in combination with CRT, we noted that the efficacy of this treatment was inversely related to the initial tumor size. The majority of patients $(62.9 \%)$ had lymph nodes (LNs) up to $5 \mathrm{~cm}$ in diameter. The highest percentage of complete regression of tumors was observed in lymph nodes with a small size $(<5 \mathrm{~cm})$ (Table 4). The most significant decrease in the size of lymph nodes was observed after the 3 injections of IIBI (within 7-10 days of treatment). The rate of lymph node regression during the subsequent IIBI injections was less pronounced.

Table 4.

Regression of lymph nodes in $H L$ patients during treatment $(C R T+I I B I)$

\begin{tabular}{|c|c|c|c|}
\hline $\begin{array}{c}\text { Average siz } \\
\text { of LN }\end{array}$ & $\begin{array}{l}\text { Before treatment } \\
\text { (number of } \\
\text { LNs) }\end{array}$ & $\begin{array}{c}\text { After treatment } \\
\text { (number of } \\
\text { LNs) }\end{array}$ & $\mathrm{P}, \chi^{2}$ \\
\hline$<2 \mathrm{~cm}$ & 19 & 4 & $\chi 2=11.706 ; P<0.001$ \\
\hline$\geq 5 \mathrm{~cm}$ & 33 & 17 & $\chi 2=7.964, \mathrm{P}<0.005$ \\
\hline$\geq 10 \mathrm{~cm}$ & 7 & 4 & $\chi 2=0.888, P>0.05$ \\
\hline
\end{tabular}

In conclusion, the clinical application of IIBI increases the efficacy of treatment. IIBI in combination with CRT induces the production of highly active endogenous IFN- $\alpha / \beta$, 
provides a marked regression of the affected lymph nodes in a short period (within 7 to 10 days) of treatment, relieves $B$ symptoms, and increases by 2 times the length of remission in patients with refractory HL.

\section{Competing interests}

The authors declare that they have no competing interests.

\section{References}

1. Evens AM, Hutchings M, Diehl V. Treatment of Hodgkin lymphoma: the past, present, and future. Nat Clin Pract Oncol 2008;5(9): 543-56.

2. Bröckelmann PJ, Engert A. The GHSG Approach to Treating Hodgkin's Lymphoma. Curr Hematol Malig Rep. 2015 Sep; 10(3):256-65.

3. Kroemer G, Galluzzi L. Immunotherapy of hematological cancers: PD-1 blockade for the treatment of Hodgkin's lymphoma. Oncoimmunology. 2015;4(6):e1008853.

4. Ansell SM, Lesokhin AM, Borrello I, Halwani A, Scott EC, Gutierrez M, et al. PD-1 blockade with nivolumab in relapsed or refractory Hodgkin's lymphoma. N Engl J Med. 2015;372(4):311-9.

5. Jahn T, Zuther M, Friedrichs B, Heuser C, Guhlke S, Abken H, Hombach AA. An IL12-IL2-antibody fusion protein targeting Hodgkin's lymphoma cells potentiates activation of NK and T cells for an anti-tumor attack. PLoS One. 2012;7(9):e44482.

6. Küppers R, Schwering I, Bräuninger A, Rajewsky K, Hansmann ML. Biology of Hodgkin's lymphoma. Ann Oncol.2002; 13 Suppl 1: 11-18.

7. Maggio E, van den Berg A, Diepstra A, Kluiver J, Visser L, Poppema S. Chemokines, cytokines and their receptors in Hodgkin's lymphoma cell lines and tissues. Ann Oncol. 2002; 13 Suppl 1: 52-56.

8. Kennedy-Nasser AA, Hanley P, Bollard CM. Hodgkin disease and the role of the immune system. Pediatr Hematol Oncol. 2011; 28(3):176-86.

9. Stein H, Bob R. Is Hodgkin lymphoma just another B-cell lymphoma? Curr Hematol Malig Rep.2009; 4(3):125-8.

10. van den Berg A, Visser L, Poppema S. High expression of the CC chemokine TARC in Reed-Sternberg cells. A possible explanation for the characteristic T-cell infiltratein Hodgkin's lymphoma. Am J Pathol. 154(6):1685-91.

11. Poppema S, van den Berg A. Interaction between host $T$ cells and Reed-Sternberg cells in Hodgkin lymphomas. Semin Cancer Biol. 2000; 10(5):345-50.

12. Skinnider BF, Elia AJ, Gascoyne RD, Patterson B, Trumper L, Kapp U, et al. Signal transducer and activator of transcription 6 is frequently activated in Hodgkin and Reed-Sternberg cells of Hodgkin lymphoma. Blood. 2002; 99(2):618-26.

13. Dunn GP, Bruce AT, Sheehan KC, Shankaran V, Uppaluri $\mathrm{R}$, Bui JD, et al. A critical function for type I interferons in cancer immunoediting. Nat Immunol. 2005; 6(7):722-9.

14. Ferrantini M, Capone I, Belardelli F. Biochimie. Interferon-alpha and cancer: mechanisms of action and new perspectives of clinical use. Biochimie 2007; 89(6-7):884-93. 15. Dunn GP1, Bruce AT, Ikeda H, Old LJ, Schreiber RD. Cancer immunoediting: from immunosurveillance to tumor escape. Nat Immunol. 2002; 3(11):991-8.
16. Swann JB, Hayakawa Y, Zerafa N, Sheehan KC, Scott B, Schreiber RD, et al. Type I IFN contributes to NK cell homeostasis, activation, and antitumor function. J Immunol 2007;178(12):7540-9.

17. Hasan UA, Caux C, Perrot I, Doffin AC, Menetrier-Caux $\mathrm{C}$, Trinchieri $\mathrm{G}$, et al. Cell proliferation and survival induced by Toll-like receptors is antagonized by type I IFNs. Proc Natl Acad Sci USA. 2007; 104(19):8047-52.

18. Shmulevitz M, Pan LZ, Garant K, Pan D, Lee PW. Oncogenic Ras promotes reovirus spread by suppressing IFN-beta production through negative regulation of RIG-I signaling. Cancer Res. 2010;70(12):4912-21.

19. Zitvogel L, Galluzzi L, Kepp O, Smyth MJ, Kroemer G. Type I interferons in anticancer immunity. Nat Rev Immunol. 2015; 15(7):405-14.

20. Decker T, Müller M, Stockinger S. The yin and yang of type I interferon activity in bacterial infection. Nat Rev Immunol. $2005 \mathrm{Sep} ; 5(9): 675-87$.

21. Gomes MT, Campos PC, de Almeida LA, Oliveira FS, Costa MM, Marim FM, et al. The role of innate immune signals in immunity to Brucella abortus. Front Cell Infect Microbiol. 2012;2:130.

22. Nagarajan UM, Sikes J, Prantner D, Andrews CW Jr, Frazer L, Goodwin A, et al. MyD88 deficiency leads to decreased NK cell gamma interferon production and $\mathrm{T}$ cell recruitment during Chlamydia muridarum genital tract infection, but a predominant Th1 response and enhanced monocytic inflammation are associated with infection resolution. Infect Immun. 2011;79(1):486-98.

23. Monroe KM, McWhirter SM, Vance RE. Induction of type I interferons by bacteria. Cell Microbiol. 2010;12(7):881-90.

24. Petropoulos D, Worth LL, Mullen CA, Lockhart S, Choroszy M, Chan KW. Interferon-alpha after autologous stem cell transplantation in pediatric patients with advanced Hodgkin's lymphoma. Bone Marrow Transplant. 2006;38(5):345-9.

25. Batty N, Hagemeister FB, Feng L, Romaguera JE, Rodriguez MA, McLaughlin P, et al. Doxorubicin, bleomycin, vinblastine and dacarbazine chemotherapy with interferon for advanced stage classic Hodgkin lymphoma: a 10-year followup study. Leuk Lymphoma. 2012;53(5):801-6.

26. Isaacs A, Lindenmann J. Pillars Article: Virus interference. I. The interferon. Proc R Soc Lond B Biol Sci. 1957; 147;258-267 27. Meissner NN, Swain S, Tighe M, Harmsen A, Harmsen A. Role of type IIFNs in pulmonary complications of Pneumocystis murina infection. J Immunol. 2005;174(9):5462-71.

28. Monroe KM, McWhirter SM, Vance RE. Induction of type I interferons by bacteria. Cell Microbiol. 2010;12(7): 881-90.

29. Sharma S, Deoliveira RB, Kalantari P, Parroche P, Goutagny N, Jiang Z, et al. Innate immune recognition of an AT-rich stem-loop DNA motif in the Plasmodium falciparum genome. Immunity. 2011;35(2):194-207.

30. de La Maza LM, Peterson EM, Goebel JM, Fennie CW, Czarniecki CW. Interferon-induced inhibition of Chlamydia trachomatis: dissociation from antiviral and antiproliferative effects. Infect Immun. 1985;47(3):719-22.

31. Buss C, Opitz B, Hocke AC, Lippmann J, Van Laak V, Hippenstiel S, et al. Essential role of mitochondrial antiviral signaling, IFN regulatory factor (IRF) 3 , and IRF7 in Chlamydophila pneumoniae-mediated IFN-beta response and control of bacterial replication in human endothelial cells. J Immunol. 2010;184(6): 3072-8. 
32. Plumlee CR, Lee C, Beg AA, Decker T, Shuman $\mathrm{HA}$, Schindler C. Interferons direct an effective innate response to Legionella pneumophila infection. J Biol Chem. 2009;284(44):30058-66.

33. Carrero JA, Calderon B, Unanue ER. Lymphocytes are detrimental during the early innate immune response against Listeria monocytogenes. J Exp Med. 2006;203(4): 933-40.

34. O’Connell RM, Saha SK, Vaidya SA, Bruhn KW, Miranda GA, Zarnegar B, et al. Type I interferon production enhances susceptibility to Listeria monocytogenes infection. J Exp Med. 2004;200(4):437-45.

35. Qiu H, Fan Y, Joyee AG, Wang S, Han X, Bai H, et al. Type I IFNs enhance susceptibility to Chlamydia muridarum lung infection by enhancing apoptosis of local macrophages. $\mathrm{J}$ Immunol. 2008;181(3): 2092-102.

36. Huang LY, Ishii KJ, Akira S, Aliberti J, Golding B. Th1-like cytokine induction by heat-killed Brucella abortus is dependent on triggering of TLR9. J Immunol. 2005; 175(6):3964-70.
37. Salcedo SP, Marchesini MI, Lelouard H, Fugier E, Jolly G, Balor S, et al. Brucella control of dendritic cell maturation is dependent on the TIR-containing protein Btp1. PLoS Pathog. 2008;4(2):e21.

38. Interferon inducer bacterial liquid.State Register of medicinal products of the Republic of Kazakhstan. 2012; IDA 42-33-68-11.

39. Jaffe ES. The 2008 WHO classification of lymphomas: implications for clinical practice and translational research. Hematology Am Soc Hematol Educ Program. 2009. 523-31.

40. KovriginaAM,ProbatovaNA.Morphoimmunohistological differential diagnosis between Hodgkin's lymphoma with lymphoid prevalence and large B-cell lymphoma. Arkh Patol. 2005; 67(4):10-6 [Article in Russian].

41. Novokhatskii AS, Cherkashina NP, Ershov FI. Accelerated method of determining the antiviral activity of interferon inducers in experimental infection. Vopr Virusol. 1979;3:3036. [Article in Russian]. 